Ивана Н. Шоргић ${ }^{1}$

Универзитет у Нишу

Филозофски факултет ${ }^{2}$

Центар за стране језике

Никола М. Татар

Универзитет у Нишу

Филозофски факултет

Центар за стране језике

\title{
ПЕРЦЕПЦИЈА АНГЛИЦИЗАМА ОД СТРАНЕ СТУДЕНАТА КОМУНИКОЛОГИЈЕ И НОВИНАРСТВА И СТУДЕНАТА АНГЛИСТИКЕ - ПСИХОЛИНГВИСТИЧКИ ПРИСТУП
}

\begin{abstract}
Овај рад бави се тиме како студенти са Департмана за комуникологију и новинарство, као и студенти Англистике перципирају новије англицизме, и то искључиво оне које у Речнику новијих англицизама „Du yu speak anglosrpski“ (Васић, Прћић и др., 2001) класификују као „потпуно неоправдане“. Ови студенти одабрани су као представници тзв. специјалних корисника језика, односно корисника језика који ће кроз деловање у оквиру својих будућих професија у великој мери утицати на употребу српског језика уопште. У складу са методолошким принципима преузетим из психолингвистике, формулисане су две хипотезе. Прва хипотеза подразумева да ће студенти оба департмана имати смањену свест о англицизмима у свом матерњем језику због уроњености у енглески као страни језик, односно свет масовних медија у коме доминирају англицизми, док друга хипотеза подразумева управо супротан сценарио: да ће њихова свест управо због поменуте „уроњености“ бити повећана. Студентима-испитаницима представљен је упитник са Ликертовом скалом на којој је требало да оцене ваљаност реченица са англицизмима или идентичних реченица са преводним еквивалентима ослањајући се на своју интуицију изворног говорника. Прикупљени подаци затим су статистички обрађени коришћењем АНОВЕ и т-теста, а резултати су потврдили другу хипотезу.
\end{abstract}

Кључне речи: неоправдани англицизми, перцепција, студенти, специјални ко-

1 ivana.sorgic@filfak.ni.ac.rs

2 Рад је настао у оквиру интерног пројекта Настава страног језика науке и струке: изазови у друштвено-хуманистичким наукама, 360/1-16-14-01, који изводи Центар за стране језике на Филозофском факултету Универзитета у Нишу. 
рисници, психолингвистика

\section{1.УВОД}

Двадесет и први век донео је за многе европске језике нешто што се до 80-их година прошлог века није могло ни наслутити. Наиме, десило се то да једно језичко подручје без директног контакта и са огромне географске удаљености врши досад невиђени лингвистички утицај на друге језике. Ради се, наравно, о америчком енглеском језику, који је за већину Европе постао свакодневица ставши раме уз раме са свим њеним матерњим језицима, и постао оно што се може назвати lingua franca, глобални језик (KRISTAL 2003), или одомаћени страни језик (PRĆIĆ 2005). Овакву ситуацију данас имамо и у српском језику, у који је амерички енглески начинио продор на свим нивоима, од фонологије до прагматике.

У светлу те чињенице, ваља се одмах на почетку оградити од језичког пуризма, било каквих вредносних судова о контакту између ова два језика, као и погрешног тумачења горепоменутог продора енглеског као нечега што се десило присилом, против воље језика примаоца, и посматрати оно чему сведочимо као феномен који треба проучити, упознати, разумети, а затим пренети сазнања ученицима и студентима са филолошких и филозофских департмана, као и тзв. спецјалним корисницима језика. Ипак, када се говори о тренутној хибридизацији енглеског и српског, односно њиховом мешању и стапању у један „производ“, Мишић Илић (2014: 339) наводи да наши наистакнутији лингвисти, иако се ограђују од језичког пуризма, у исто време често упозоравају на тренутно стање у језику и позивају на адекватну употребу англицизама, апелујући на ширење и промоцију језичке културе. На ту тему Бугарски каже:

„А држава треба да створи институционални оквир који омогућава водење организоване и систематске бриге о језику. При томе језик могу најбоље чувати и развијати сами његови говорници, јер без њиховог интересовања и ангажовања никаква решења наметнута одозго или понуђена са стране немају изгледа на успех. Зато је потребно ширити друштвену свест о важности језика и могућностима које он пружа. Ово се пак не постиже идеолошки или политички инспирисаним прокламацијама, него дугорочним деловањем на подизању општег нивоа писмености и језичке културе - а у томе, као што је познато, стојимо веома лоше.“ Бугарски (2005: 267)

Англицизми као свеприсутни језички феномен, а са њима и културна и језичка англикализација у савременим лингвистичким круговима су изузетно популарна тема за истраживање, па данас имамо и међународно удружење GLAD - The Global Anglicism Database, или Глобална база англицизама, која обухвата публикације и истраживања лингвиста из свих делова света. Са друге стране, у настави језика, како у средњим 
школама, тако и на факултетима, још увек се не посвећује велика пажња англицизмима у матерњем језику, што указује на често присутан раскорак између науке и праксе, односно теоријске и примењене лингвистике. Горенаведене чињенице послужиле су као главни мотив за ово истраживање перцепције англицизама, у коме су за испитанике одабрани студенти са Департмана за комуникологију и новинарство и Департмана за Англистику Филозофског факултета у Нишу. Поред тога што спадају у будуће „специјалне кориснике језика“, који ће својим деловањем имати велики утицај на употребу језика у општој популацији, студенти-испитаници такође припадају и старосној групи коју управо дефинише поменути језички хибрид енглеског и српског. Ради се, како каже Прћић (2005: 78) претежно о урбаним младим људима који језичку културу, па и културу уопште усвајају првенствено преко масовних медија, и за које је, додаје Бугарски (2005: 125) „енглески ..., поред компјутера (којима је он такође «матерњи језик»),... нешто што се подразумева и без чега неће моћи да се уклопе у главне токове живота у овом веку“.

Што се тиче угла из кога су англицизми у овом раду посматрани, уместо традиционалне анализе, која је обично у духу структурализма, ова студија англицизме посматра из угла психолингвистике, те је фокус померен са уобичајеног испитивања текстуалног корпуса на анализу перцепције англицизама код студената-испитаника. У том смислу формулисане су и две хипотезе:

1. Студенти оба департмана превидеће англицизме у корпусу, тј. оцениће их сличним оценама као и преводне еквиваленте, због чињенице да су „уроњени” у англо-амерички језик, културу и књижевност, односно свет масовних медија којима доминирају англицизми.

2. Студенти оба департмана оцениће реченице са преводним еквивалентима вишим оценама у односу на англицизме, јер су кроз наставу српског језика, односно наставу превођења развили свест о овом феномену у свом матерњем језику.

У наредном пасусу биће представљен преглед релевантне литературе, који за циљ има да ово истраживање смести у одговарајући теоријски оквир.

\section{2. ПРЕГЛЕД ЛИТЕРАТУРЕ СА ИСТОРИЈСКИМ ОСВРТОМ}

Контакт европских језика са енглеским, тачније његовим британским варијететом, јавио се веома рано, интензивирао у 17. и 18. веку, и оставио уочљиве трагове у вокабулару ових језика (FILIPOVIĆ 1986:50). Данас је, међутим, амерички варијетет тај који има глобални утицај, првенствено због тога што се, по речима Кристала „нашао на правом месту 
у право време“, односно због чињенице да су САД доживеле врхунац економске и војне моћи баш у 19. и 20. веку, када је почео и незаустављиви развој и успон технологије, мултинационалних компанија и масовних медија (KRISTAL 2003: 10). Захваљујући томе, данашња слика заступљености страних језика у Европи изгледа овако: 41\% говори енглески, док, насупрот томе имамо само 19\% говорника француског, 10\% немачког, 7\% шпанског и 3\% италијанског као страног језика (EVROPSKA KOMISIJA, 2002: 6).

Како пише Филиповић (1986: 19-28), језици у контакту пробудили су интересовање лингвиста још у 19. веку. У то време доминантан је био став да „мешани“ језици заправо не постоје, те да је позајмљивање ограничено на план лексике. Међу тадашњим лингвистима који су износили овакве тврдње најпознатији су били Расмус Раск, Џејкоб Грин и Макс Милер. Тридесетак година касније, амерички лингвиста Витни (1881), износи потпуно супротне тврдње, у којима каже да се и читав језик једног народа може пренети на други, а придружује му се и Шукерт, први креолист, који је сматрао да заправо не постоји потпуно „чист“ језик, те да су сви језици донекле мешани. Због овог, за то време, радикалног становишта, Шухерт се и сматра зачетником савремених проучавања језичких контаката.

Као што је то чест случај у многим доменима лингвистике, ни у раним фазама проучавања језичких контаката није постојала јединствена дефиниција мешаног језика, а наставила су да егзистирају три опречна мишљења: да нема мешаних језика, да постоје одређени мешани језици, као и да су сви језици мешани.

У 20. веку су напуштени термини „мешани језик“ и „хибридни језик“ као нејасни и неодговарајући, у корист „језичког позајмљивања“ , а контакт између два језика почео је све више да гравидира ка билингвизму и билингвалном говорнику као тачки у којој долази до језичког додира и која је извор језичке интерференције, тј. одступања од норме као последице познавања два или више језика. С тим у вези, хибридизација језика на нивоима мимо лексичког (фонолошком, морфолошком, прагматичком), доводи се у везу са степеном билингвизма језичке заједнице. У исто време, захваљујући Вајнрајху и Хејгену, све већи акценат се ставља на социолингвистичке и психолошке аспекте билингвизна и контактних ситуација, и научна заједница се позива на интердисциплинарни приступ контактној лингвистици (VINFORD, 2003: 9).

Хронолошки приказ промена у домену језичких контаката током последњих педесет година 20. века на следећи начин сумира Ајдуковић (2004:10):

1. Педесете године обележила су истраживања језичког позајмљивања на морфолошком, фонолошком, синтаксичком и лексичком нивоу, као и радови Вајнрајха (VAJNRAJH 1953) и Е. Ха- 
угена (HAUGEN 1950; 1953).

2. Након тога, већ шездесетих година фокус се ставља на интеграцију језичких елемената код позајмљивања, а доминантни приступ је социолингвистички. Најзначајнији су радови Мекија, Филиповића и Куртбокеа (MEKI 1970, FILIPOVIĆ 1968, KURTBOKE 1998).

3. Седамдесетих година акценат је на повезивању лингвистичких и ванлингвистичких нивоа анализе у контактним ситуацијама, а интересовање се помера са појединца на групу и њен политички идентитет. Интерференција, до тада доминантан термин у проучавању језичких контаката, замењује се терминолошки појмом трансфера.

4. Осамдесете године коначно су изнедриле појам контактна линвистика (NELDE 1983:12). У сфери језичких контаката најживље је интересовање за вишејезичност, и то у различитим узрастима, здравим и патолошким условима. Популарне теме постају и пребацивање кода, као нестајање језика.

5. Коначно, деветесете године означила је теорија копирања кода (JOHANSON 1992) и модел матричног језичког оквира. Говори се о и о да типа контактних ситуација: ситуацији стабилности и ситуацији напада (TOMASON 1995). Код нас се појаваљују и први контактолошки речници (FILIPOVIĆ 1990, AJDUKOVIĆ 1997).

У 21. веку и даље је актуелно велико интересовање за језичке контакте и њихове исходе и производе, нарочито других језика са америчким енглеским. Пуно се говори о утицају двојезичности на когнитивне способности и функције, нарочито из угла психолингвистике која испитује разне аспекте функционисања двојезичног ума. О овоме је доста писао Грожан (GROSJEAN 2013), који се бавио и оповргавањем популарних митова везаних за двојезичност. Код нас се контактне ситуације ретко посматрају из угла психолингвистике, али су зато изузетно популарни традиционалан структуралистички, као и социолингвистички приступ англицизмима, и њиме се последњих година најактивније баве Бугарски, Ајдуковић, Прћић, Панић-Кавгић, Мишић-Илић и други.

Тематско и хронолошко кретање од језичког позајмљивања до двојезичности и двојезичног говорника као тачке у којој се спајају два или више језика могло би се закључити чињеницом да је данас већина светске популације двојезична, и то тако да је један од језика који говори баш енглески (ROMEJN 2017). У Србији је, као и у многим другим језицима, енглески одавно добио посебан статус најпре фаворизовањем у настави страних језика. Један од разлога за фаворизацију свакако је и ви- 
сок проценат заступљености енглеског језика у академској литератури, пре свега у међународним стручним часописима. Ако томе придодамо отвореност за језичке и културне утицаје који су долазили преко масовних медија, добијамо слику какву имамо данас. индиректан, или како га Винфорд (2003: 30) назива, „неформалан“ (casual), по својим особинама овај језички контакт је превазишао пуко лексичко позајмљивање које иначе карактерише контактну ситуацију у којој су два језика географски удаљена. Због свега наведеног, Прћић (2005: 14) инсистира на томе да се енглески више не може сматрати прототипским страним језиком, већ га означава као одомаћени страни језик. Чињеница да су се околности умногоме промениле када је реч о контакту српског и енглеског језика може се видети и по самој дефиницији англицизма. У књизи Англицизми у хрватском или српском језику, Рудолф Филиповић дао је следећу дефиницију:

„Англицизам је свака ријеч преузета из енглеског језика која означава неки предмет, идеју или појам као суставне дјелове енглеске цивилизације; она не мора бити енглеског поријекла, али мора бити адаптирана према суставу енглеског језика и интегрирана у енглески вокабулар“ (FILIPOVIĆ 1990:17).

Оно што се на први поглед може приметити је да се ова дефиниција од пре 30 година фокусира првенствено на реч, односно лексику, што примењено на данашњи контекст покрива свега око 20\% онога што англицизам представља. Прћић увиђа потребу за проширивањем дефиниције, те укључивањем у њу јединица већих и мањих од речи, различитих степена интеграције, као и чињенице да се сем на лексичком, англицизми јављају и на ортографском, фонолошком, морфо-синтактичком, семантичком и прагматичком ниво. Нову језичку реалност контакта између енглеског и српског језика тако одсликава и дефиниција по којој англицизам представља:

„...општу реч или везану морфему из енглеског језика која се, с различитим степеном интегрисаности, употребљава у српском језику, док у другом, донекле неуобичајеном значењу овог термина, под англицизмом подразумевамо и оне речи, синтагме или реченице у српском чија употреба одражава и/или следи различите норме енглеског језика - ортографску, фонолошку, граматичку, семантичку или прагматичку“ (PRĆIĆ 2004:114).

И док је неоспорно то да англицизми неретко служе да попуне реалне језичке празнине или додају нијансу у значењу која се не може наћи у матерњем језику, истина је да има и много таквих англицизама које се у континууму од „потпуно оправданих“ до „потпуно неоправданих“ налазе у потоњој категорији. За њих Прћић (2005:120) каже: „Ан- 
глицизам је сасвим неоправдан уколико већ постоји домаћа или одомаћена реч или израз за дати страни садржај. Такви су нпр. кастинг или casting према аудиција; фан према обожавалац...“.Управо овај тип англицизама ексцерпиран је из Речника новијих англицизама „Du yu speak anglosrpski“ (Васић, Прћић и др., 2001) приликом сачињавања корпуса, због претпоставке да би, као англицизам који највише одудара од српске језичке норме код студената-испитаника изазвао и потенцијално најинтензивнију реакцију.

Што се тиче одреднице “новији”, аутори речника у предговору наводе да су под тиме подразумевали англицизме који су у српски језик ушли у претходних тридесетак година, као и оне старије који су у том временском оквиру добили нова значења. Англицизми су ексцерпирани из дневне штампе, часописа, радијских и телевизијских емисија, као и из говорног језика.

Анализа англицизама помоћу методе „позајмљене“ из психологије, односно психолингвистике, упитника са Ликертовом скалом, којом се бави овај рад, могла би да пружи некакав увид у то како говорници српског језика перципирају овај одомаћени страни језик и да понуди смерове за даља истраживања. Једно од таквих допунских истраживања свакако би требало да укључи мерење времена одзива, како би се видело да ли је за когнитивно процесирање англицизама потребно више времена и колико више у односу на, рецимо, преводне еквиваленте.

У наредном одељку ће, стога, бити више речи о методологији истраживања, корпусу и одабиру испитаника за овај рад.

\section{3. МЕТОДОЛОГИЈА ИСТРАЖИВАҢА}

\section{1. Инструмент}

Инструмент у овом истраживању представља укупно 100 реченица, од чега је 25 реченица садржало англицизме, 25 одговарајуће еквиваленте на српском језику, док се преосталих 50 реченица нашло у упитнику у функцији филера. Англицизми коришћени у истраживању преузети су из Речника новојих англицизама (Васић, Прћић и др., 2001), а одабир је вршен на основу критеријума „степен оправданости“. Наиме у „Водичу кроз речник“ (2001:14) који претходи самим одредницама, у одељку број 6 под називом „Индекс интегрисаности у српски језик“ налазе се објашњења специфичних квалификатора које су аутори користили. Тако се од три поља која прате сваку лему, у левом налази оцена обличке адаптације (од 0 - неадаптирана реч, преко 1 - реч која је адаптирана по облику, суфиксима за падеж и род, до 2 - именичка и придевска изведеница), у средњем оцена значењске адаптације (такође од 0 - реч за коју постоји устаљени српски еквивалент, преко 1 - реч за коју постоји српски евивалент са приближним значењем, до 2 - реч за коју не посто- 
ји српски еквивалент), а у десном оцена оправданоси употребе (- за реч која је непотребна, јер за њу постоји српски еквивалент, \pm за реч која је прихватљива у одређеним контекстима, + за реч која је потребна јер означава нови појам). У истраживање је, дакле, укључено 25 одредница са ознаком 00-, који су употребљени као детерминативи, те представљају англицизме и на лексичком и на синтаксичком нивоу.

Корпус са англицизмима састављен је тако што су одреднице из горепоменутог речника употребљене у 25 реченица ${ }^{3}$ сличне дужине, чије се значење односи на свакодневне ситуације попут похађања факултета и курсева, коришћења интернета, или пак на свет уметности и забаве. С обзиром на чињеницу да је формулација реченица једна од кључних ствари на којој почива успех психолигвистичких испитивања, водило се рачуна и о томе да корпус чини емотивно необојен говор, као и да структура реченице пре и после циљног региона, тј. англицизма буде уједначена.

Још један од круцијалних фактора од којих зависи успех истраживања јесте адекватна формулација филера, као и довољан број истих. Идеално је да број филера буде или једнак броју испитиваних реченица, или дупло већи. У овом истраживању, број филера једнак је броју испитиваних реченица, јер је постојала бојазан да би њихово дуплирање довело до превеликог когнитивног оптерећења испитаника, због чега би и њихови одговори постајали мање поуздани пред крај анкетирања. Филери су садржали идентичне речи или фразе као циљне реченице корпу$\mathrm{ca}$, али не англицизме и њихове преводне еквиваленте. Један од примера сета од четири реченице, где једна садржи англицизам, друга преводни еквивалент, а преостале две идентичну реч или фразу као циљне реченице је следећи:

1. Објавила је камбек нумеру “Живот је леп”, за коју је снимљен и спот. (Реченица са англицизмом)

2. Објавила је повратничку нумеру “Живот је леп”, за коју је снимљен и спот. (Реченица са преводним еквивалентом)

3. Спот који је снимила прошле године прати њена сећања из младости и детињства. (Филер 1, садржи реч „спот“ употребљену у примеру са англицизмом и преводним еквивалентом, како би смањио транспарентност истраживања)

4. Објавила је недавно да ће све своје нумере промовисати преко интернета. (Филер 2, садржи реч „нумера“ коришћену у примеру са англицизмом и српским еквивалентом, као и реч „интернет“ коришћену у многим другим примерима како би се смањила транспарентност истраживања)

3 Реченице нису преузимане из Речника новијих англицизама, већ су их састављали сами аутори. 
Остали англицизми коришћени у истраживању могу се видети у следећој табели, где су представљени као део синтагме у оквиру које врше функцију детерминатива:

Табела 1. Синтагме са англицизмима коришћеним у истраживању

\begin{tabular}{|l|l|}
\hline 1. Адвертајзинг агенција & 14. Фикшн граница \\
\hline 2. Афтершејв лосион & 15. Фитнес опрема \\
\hline 3. Апгрејд паковања & 16. Флешбек прича \\
\hline 4. Бизнис курс & 17. Фолк звук \\
\hline 5. Боди-арт наступ & 18. Геј етикета \\
\hline 6. Браузер прозор & 19. Хепиенд верзија \\
\hline 7. Бутлег верзија & 20. Хотлајн разговор \\
\hline 8. Чет програм & 21. Хоумбенкинг систем \\
\hline 9. Диџест верзија & 22. Камбек нумера \\
\hline 10. Џамбо пано & 23. Кавер верзија \\
\hline 11. Фан клуб & 24. Кингсајз груди \\
\hline 12. Фастфуд ресторан & 25. Кокпит спреј \\
\hline 13. Фер-плеј играч & \\
\hline
\end{tabular}

\section{2. Испитаници}

У истраживању је учествовало укупно 100 студената II и III године, од тога 47 са Департмана за комуникологију и новинарство и 53 са Департмана за англистику. Упитници направљени у апликацији Гугл формс (Google forms) студентима су послати електронским путем, преко линка који генерише са̂м програм. У истраживање су укључени студенти са две године студија, јер се није очекивао велики одзив, првенствено због одсуства мотивације код студената да се учествује у нечему што није у директној вези са студијама.

Студенти новинарства посебно су занимљиви као испитаници, јер са једне стране морају да имају релативно висок ниво знања из српског језика, а са друге стране уроњени су у свет медија којим доминира обиље различитих англицизама (који су првенствено резултат стихијског преузимања терминологије из енглеског језика, као и нестручног превођења и адаптације текстова на овом језику). Са друге стране, за студенте англистике може се претпоставити са једне стране да због свакодневне изложености енглеском језику немају претерано развијену свест о англицизмима у свом матерњем језику, а са друге да због наставе превођења ипак имају некакво знање о њиховој коегзистенцији са одговарајућим српским еквивалентима. 
Од обе групе студената-испитаника се, дакле, могло подједнако очекивати и да имају повећану свест о англицизмима, као и да им потпуно промакну у корпусу на којем се вршило испитивање, јер их због горенаведених околности и не доживљавају као нешто што одудара или не припада српском језику. У складу са тим су и постулиране су две супротстављене хипотезе, које су већ поменуте и у уводном делу чланка:

1. Испитаници са оба департмана превидеће англицизме у корпусу због свеприсутности англо-америчког језика у свету културе и књижевности, односно масовних медија.

2. Испитаници са оба департмана ће, због специфичних студијских програма које похађају, реченице са преводним еквивалентима оценити вишим оценама у односу на англицизме, јер имају повећану свест о присуству англицизама у матерњем језику.

\section{3. Процедура}

У овом истраживању коришћена је једна од најједноставнијих метода у психолингвистици, упитник са психометрјском, односно Ликертовом скалом. Упитник спада у тзв. офлајн методе, односно методе којима се може мерити исход когнитивног процесирања након што се оно завршило. Иако не бележи дешавања за време језичког процесирања попут неких софистициранијих метода које се ослањају на високу технологију, упитник није ништа мање вредан од осталих психолингвистичких метода и штавише, често се користи уз друге методе као додатни или допунски.

За потребе овог истраживања коришћен је упитник затвореног типа који је био направљен на бесплатној онлајн платформи Гугл формс (Google forms) и послат студентима путем линка који генерише сам програм. Укупно стотину реченица, колико се нашло у упитнику, рандомизовано је помоћу опције shuffle question order коју нуди сам програм, те су се оне приказивале насумичним и сваком испитанику другачијим редоследом. Испитаницима се уз сваку приказану реченицу нудила Ликертова скала са шест подеока, од 0 до 6, где је 0 дефинисана као „потпуно неприхватљиво“, а 6 као „потпуно прихватљиво“. Неки од примера студентских оцена приказани су у наставку: 
Oni već dugo rade za poznatu advertajzing agenciju.

47 responses

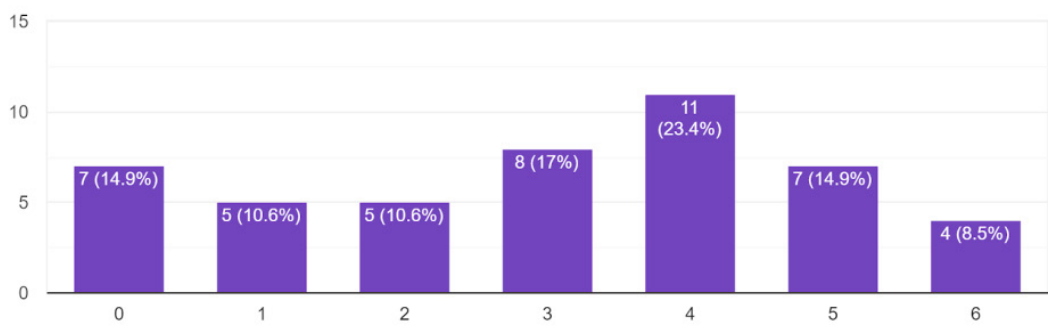

Графички приказ 1. Оцене студената новинарства $u$ комуникологије за пример са англицизмом „адвертајзинг (агенција)“

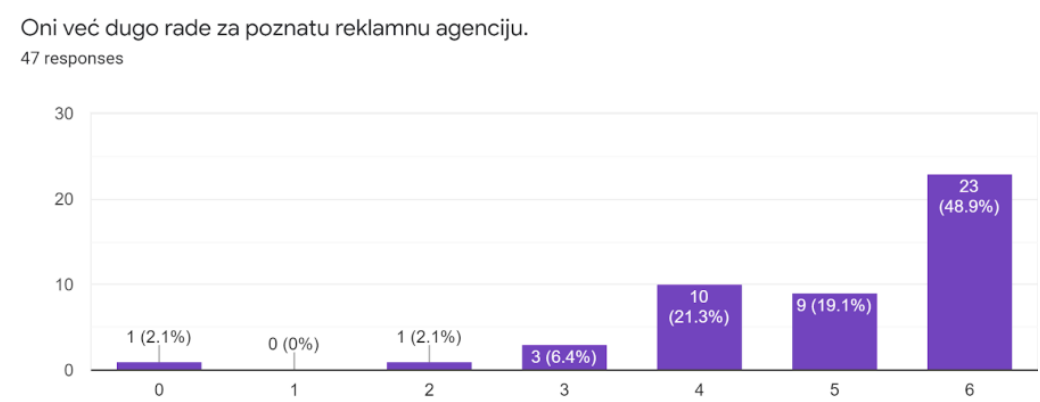

Графички приказ 2. Оцене студената англистике за пример са преводним еквивалентом „рекламна (агенција)“

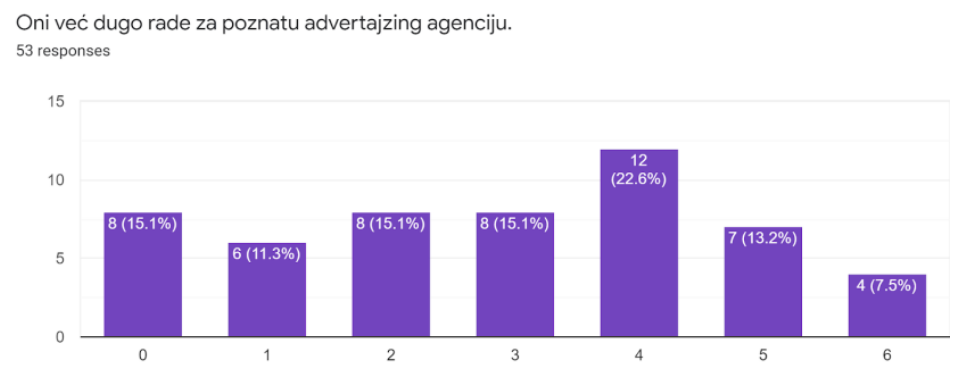

Графички приказ 3. Оцене студената англистике за пример са англицизмом „адвертајзинг (агенција)“ 


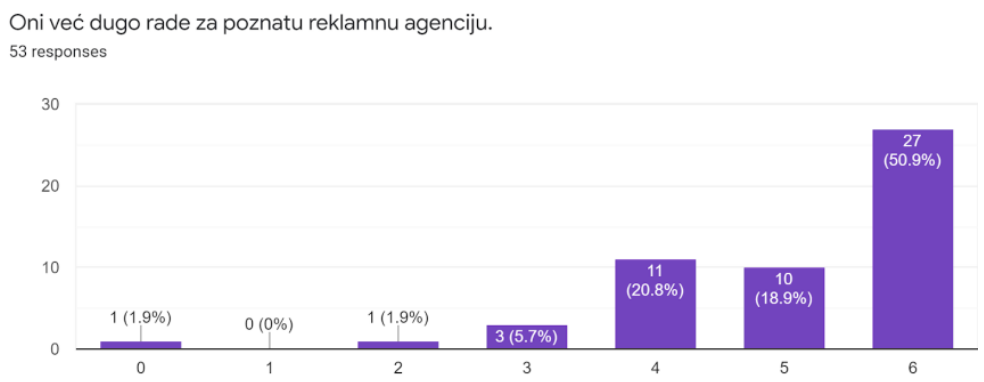

Графички приказ 4. Оцене студената англистике за пример са преводним еквивалентом „рекламна агенција“

Резултати спроведеног истраживања обрађени су статистички једносмерним АНОВА тестом, као и т-тестом за независне узорке и представљени су у наредном одељку.

\section{4. РЕЗУЛТАТИ}

Као што је већ поменуто у претходном одељку, испитаници-студенти су у упитнику са Ликертовом скалом, који је направљен на отвореној платформи Гугл формс, реченице из корпуса оцењивали оценама од 0 до 6, где је 0 дефинисано као „потпуно неприхватљиво“, а 6 као „потпуно прихватљиво“. Приликом потоње обраде одговора статистичком анализом у обзир су узете само реченице са англицизмима (25) и реченице са преводним еквивалентима (25). Резултати једносмерне АНОВЕ и т-теста за независне узорке представљени су у следећим табелама:

Табела 2. Средње вредности оцена које су додељене англицизмима

\begin{tabular}{|l|c|c|c|c|c|c|c|c|}
\hline & H & $\begin{array}{c}\text { Ср. } \\
\text { Вред. }\end{array}$ & СД & СГ & \multicolumn{2}{|c|}{$\begin{array}{c}\text { 95\% Интервал поу- } \\
\text { зданости за средњу } \\
\text { вредност }\end{array}$} & Мин & Мак \\
\cline { 5 - 7 } & & & & & $\begin{array}{c}\text { Доња } \\
\text { граница }\end{array}$ & $\begin{array}{c}\text { Горња } \\
\text { граница }\end{array}$ & & \\
\hline Ком-Нов & 25 & 3.0776 & .90507 & .18101 & 2.7040 & 3.4512 & 1.76 & 5.14 \\
Англисти & 25 & 2.9582 & 1.24069 & .24814 & 2.4461 & 3.4703 & .89 & 5.58 \\
Укупно & 50 & 3.0179 & 1.07648 & .15224 & 2.7120 & 3.3239 & .89 & 5.58 \\
\hline
\end{tabular}

У првој табели можемо видети средње вредности оцена које су студенти новинарства и англистике давали англицизмима у корпусу. Ове вредности су веома сличне, и код првих је просечна оцена 3,08, а код других 2,95. Уколико размотримо две хипотезе постављене на почетку истраживања, које кажу да ће испитаници са оба департмана превидети англицизме у корпусу због свеприсутности англо-америчког језика 
(1), односно да ће испитаници са оба департмана реченице са преводним еквивалентима оценити вишим оценама, јер имају повећану свест о присуству англицизама у матерњем језику (2), сличне оцене додељене англицизмима можемо протумачити као потврду предвиђене сличности у њиховој перцепцији код студената оба департмана.

Друга табела показује да разлике у оценама између две групе нису статистички значајне, чиме се, дакле, још једном потврђује да студенти оба департмана имају сличну перцепцију англицизама:

Табела 3. Разлика $у$ оценама англицизама између две групе студенатаиспитаника

\begin{tabular}{|l|l|l|l|l|l|}
\hline & Збир квадрата & дф & Ср. вред. квадрата & F & 3начај \\
\hline Међу групама & .178 & 1 & .178 & .151 & .699 \\
Унутар групе & 56.603 & 48 & 1.179 & & \\
укупно & 56.781 & 49 & & & \\
\hline
\end{tabular}

У следећој табели приказане су средње вредности оцена које су студенти два департмана дали реченицама са преводним еквивалентима. Код новинара просечна оцена је 4,80, а код англиста 4,96. Као и код оцена за англицизме, и код преводних еквивалената имамо веома сличне оцене код оба департмана, што је такође у складу са формулацијом обе постављене хипотезе. На први поглед види се и да је укупна просечна оцена за преводне еквиваленте $(4,88)$ већа него она за англицизме $(3,02)$, што указује на чињеницу да студенти имају повећану свест о присуству непотребних англицизама у свом језику, те да суочени са избором радије бирају преводне еквиваленте.

Табела 4. Средње оцене преводних еквивалената код оба департмана

\begin{tabular}{|c|c|c|c|c|c|c|c|c|}
\hline & \multirow[t]{2}{*}{$\mathrm{H}$} & \multirow[t]{2}{*}{$\begin{array}{c}\text { Ср. } \\
\text { Вред. }\end{array}$} & \multirow[t]{2}{*}{$\begin{array}{l}\text { Стд. } \\
\text { дев. }\end{array}$} & \multirow[t]{2}{*}{$\begin{array}{c}\text { Стд. } \\
\text { грешка }\end{array}$} & \multicolumn{2}{|c|}{$\begin{array}{c}\text { 95\% Интервал поу- } \\
\text { зданости за средњу } \\
\text { вредност }\end{array}$} & \multirow[t]{2}{*}{ Мин. } & \multirow[t]{2}{*}{ Макс } \\
\hline & & & & & $\begin{array}{c}\text { Доња } \\
\text { граница }\end{array}$ & $\begin{array}{c}\text { Горња } \\
\text { граница }\end{array}$ & & \\
\hline Ком-Нов & 25 & 4.7967 & .49608 & .09922 & 4.5920 & 5.0015 & 3.61 & 5.53 \\
\hline Англисти & 25 & 4.9627 & .81100 & .16220 & 4.6279 & 5.2974 & 2.29 & 5.84 \\
\hline Укупно & 50 & 4.8797 & .67060 & .09484 & 4.6891 & 5.0703 & 2.29 & 5.84 \\
\hline
\end{tabular}

Слично као и код англицизама, АНОВА тест је показао да између две групе не постоји статистички значајна разлика у оценама, што се може видети у Табели 4:

Табела 5. Разлике $у$ оценама преводних еквивалената код оба департмана

\begin{tabular}{|c|c|c|c|c|c|}
\hline & 3бир квадрата & дф & Ср. вред. квадрата & F & 3начај \\
\hline Међу групама & .344 & 1 & .344 & .762 & .387 \\
Унутар групе & 21.691 & 48 & .452 & & \\
\hline
\end{tabular}




\begin{tabular}{|l|l|l|l|l|l|}
\hline Укупно & 22.036 & 49 & & & \\
\hline
\end{tabular}

Коначно, када се збирне оцене за англицизме и преводне еквиваленте код обе групе статистички обраде т-тестом за независне узорке, добијамо статистички значајну разлику о оценама прихватљивости англицизама насупрод преводних еквивалената. То се може видети у Табели 6:

Табела 6. Поређење збирних оцена за англицизме и преводне еквиваленте

\begin{tabular}{|c|c|c|c|c|c|c|c|c|}
\hline \multirow[t]{3}{*}{ Ср. Вред. } & \multicolumn{5}{|c|}{ Paired Differences } & \multirow[t]{3}{*}{$\mathrm{T}$} & \multirow[t]{3}{*}{ дф } & \multirow[t]{3}{*}{$\mathrm{p}$} \\
\hline & \multirow[t]{2}{*}{ Стд. дев. } & \multirow[t]{2}{*}{$\begin{array}{l}\text { Стд. } \\
\text { греш. }\end{array}$} & \multicolumn{3}{|c|}{$\begin{array}{c}\text { 95\% Интервал поузданости за } \\
\text { средњу вредност }\end{array}$} & & & \\
\hline & & & Доња & Горња & & & & \\
\hline Пар 1 Англ. & -1.86177 & 1.18019 & .16690 & -2.19718 & -1.52636 & -11.155 & 49 & .000 \\
\hline
\end{tabular}

Поређењем збира оцена за англицизме са збиром оцена преводних еквивалената код оба департмана може се закључити да међу њима постоји статистички значајна разлика. Наиме, студенти оба департмана оценили су преводне еквиваленте вишом оценом, у складу са претпоставком изнетом у другој хипотези. Нешто више о самим резултатима и њиховој интерпретацији биће речено у последњем одељку.

\section{5. ЗАКЉУЧАК}

Овај рад бавио се феноменом англицизама у контексту све интензивнијег посредног контакта европских језика, па и српског, са америчким варијететом енглеског језика. Англицизми и језички контакти чине плодно тло за различите видове лингвистичких студија и анализа, а у овом истраживању акценат је стављен на то како студенти два департмана Филозофског факултета у Нишу перципирају новије англицизме у српском, означене као „непотребне“ јер за концепт који означавају већ постоји одговарајућа реч у матерњем језику. Студенти-испитаници одабрани су због чињенице да спадају у тзв. специјалне кориснике језика, јер ће кроз своју будућу професију, кроз медије, односно наставу, у знатној мери утицати на употребу српског језика. Такође, као што је већ поменуто, испитаници припадају и посебној групи младих, урбаних корисника, који су у великој мери уроњени у енглески језик (понајвише посредством масовних медија) и на њему заснивају свој идентитет. Са друге стране избор англицизама вршен на основу степена њихове оправданости, па је одабир пао на оне потпуно неоправдане.

У складу са принципима психолингвистике, из које је преузет теоријски оквир и методологија за ово истраживање, на почетку студи- 
је формулисане су две хипотезе. Одмах је претпостављено да ће два департмана слично оцењивати прихватљивост реченица са англицизмима, односмо преводним еквивалентима, јер су због саме природе студија, тј. уроњености новинара у свет масовних медија којима доминирају англицизми, односно наставе превођења где се стално компарирају и контрастирају енглеске лексеме и њихови преводни еквиваленти, ови студенти у непрестаном додиру са позајмљеницама у свом матерњем језику. Ипак, прва хипотеза оставила је простор да управо због окружења које је засићено англицизмима, студенти ових департмана немају повећану свест о њима, већ да их доживљавају као пуноправне синониме српских еквивалената. Друга, супротстављена хипотеза претпоставила је да ће гореописано окружење потпомогнуто наставом српског језика код новинара, односно наставом превођења код студената енглеског резултирати повећаном свешћу о англицизмима у српском, што би за последицу имало оцењивање реченица у корпусу које их садрже нижим оценама.

Статистичком обрадом података АНОВОМ и т-тестом за независне узорке показало се да је потврђена друга хипотеза, јер су преводни еквиваленти из корпуса оцењени вишом оценом $(4,88)$ него реченице са англицизмима $(3,02)$. Овим је доказано да студенти новинарства и англистике, као будући специјални корисници енглеског језика итекако имају повећану свест о англицизмима, упркос контексту у коме сведочимо константном утицају америчког енглеског језика на њихов матерњи на свим језичким нивоима.

Битно је нагласити још једном да овај рад нема за циљ да промовише језички пуризам, нити сматра да би било који језик могао да опстане без промена и уношења елемената других језика у свој систем. Управо због тога су и одабрани англицизми означени као потпуно неоправдани, јер они не уносе никакву нову нијансу значења у језик прималац, о чему би требало да постоји свест макар код горепоменутих специјалних корисника. Овај рад је, дакле, показао, да суочени са лингвистичким избором, студенти-испитаници радије бирају преводне еквиваленте но неоправдане англицизме, из чега можемо да закључимо да код њих постоји повећана свест о овој врсти англицизама, односно да се они перципирају као елементи нешто нижег ранга у односу на одговарајуће еквиваленте из српског језика. Овакви резултати могли би се интерпретирати као доказ да језичка култура и ваљана употреба англицизама на које позивају Бугарски, Прћић и други, заправо и није тако недостижна као што се често мисли. Наиме, иако се млади у говору и разговору са вршњацима у великој мери користе англицизмима, у другачијем контексту итекако доживљавају англицизме, бар оне непотребне, као лошији избор у односу на преводне еквиваленте.

Свакако би даља истраживања требало да укључе мерење времена одзива приликом читања/перцепције реченица са англицизмима у 
односу на оне са преводним еквивалентима, како би се видело да ли и у којој мери англицизми стварају комуникацијску шум. Било би добро урадити и истраживање које би узело у обзир критеријум фреквентности англицизама, а одабир испитника проширити и на студенте других департмана и факултета. На крају, најважније би било створити трајну комуникацију између истраживача и наставника основних и средњих школа, чиме би сви емпиријски добијени подаци потенцијално обликовали наставу како матерњег, тако и енглеског језика.

\section{Цитирана литература}

АЈДУКОВИЋ 2004: Ајдуковић, Јован. Увод у лексичку контактологију. Теорија адаптације русизама. Изд. Београд: Фото футура, 2004.

БУГАРСКИ 2005: Бугарски, Ранко. Језик и култура. Изд. Београд: Библиотека XX век

COMISSION OF THE EUROPEAN UNION 2002: Promoting language learning and linguistic diversity - Consultation. Брисел: Европска унија. Преузето 7.6.2019. са сајта: http//:ec.europa.eu/education/policies/lang/policy/ consult/consult_en_pdf

КРИСТАЛ 2003: Crystal, David. English as a Global Language. Изд. Кембриџ: Сатbridge University Press, 2003.

ФИЛИПОВИЋ 1986: Филиповић, Рудолф. Теорија језика у контакту. Изд. Загреб: Југословенска академија знаности и уметности, 1986.

ФИЛИПОВИЋ 1990: Филиповић, Рудолф. Англицизми у хрватском или српском језику: поријекло, развој, значење. Изд. Загреб: Југославенска академија знаности и умјетности: Школска књига, 1990.

МИшИЋ ИЛИЋ 2014: Мишић Илић, Биљана. (2014). Is there life in Serbia without Anglicisms? A pragmatic view. У Т. Прћић, М. Марковић (ур.), Енглески језик и англофоне књижевности у теорији и пракси. Зборник у част Драгињи Перваз (353-371). Нови Сад: Филозофски факултет.

ПРЋИћ 2004: Прћић, Твртко. О англицизмима из четири различита, али међуповезана угла. Зборник Матице српске за филологију и лингвистику, 47: 113-129, 2004.

ПРЋИЋ 2005: Прћић, Твртко. Енглески у српском. Изд. Нови Сад: Змај, 2005. POMEJH 2017: Romaine, Suzanne. Multilingualism. У: The Handbook of Linguistics (Уp: M. Aronoff и J. Rees-Miller). doi:10.1002/9781119072256.ch26, 2017. ВИНФОРД 2003: Winford, Donald. An Introduction to Contact Linguistics. Изд. Оксфорд: Blackwell Publishing, 2003.

\section{Речник}

ВАСИЋ, ПРЋИЋ, НЕЈГЕБУЕР 2001: Васић, Вера, Прћић, Твртко, Нејгебауер, Гордана. Do yu speak anglosrpski? Речник новијих англииизама, друго издање. Нови Сад: Змај, 2001. 
Nikola Tatar

Ivana Šorgić

\section{HOW STUDENTS OF JOURNALISM AND ENGLISH PERCEIVE ANGLICISMS - A PSYCHOLINGUISTIC APPROACH}

The present paper deals the way students from the departments of Communicology and Journalism, and English Language and Literature at the Faculty of Philosophy in Niš perceive what was classified as fully unjustified recent anglicisms by The Dictionary of Recent Anglicisms (Prćić \& Nejgebauer, 2001). These students in particular were chosen as the future "special language users", i.e. language users who have a considerable influence on the use of Serbian through their chosen careers. In accordance with the methodological principles taken from the field of psycholinguistics, two hypotheses were formulated - one presupposing that immersion in English as a foreign language and the world of mass media dominated by anglicisms for students of Communicology and Journalism, and English Language and Literature, respectively will lead to decreased awareness of the presence of anglicisms in Serbian, and the other which claims the exact opposite: that the students will demonstrate greater awareness of anglicisms precisely because of the immersion. The student respondents were presented with a questionnaire and asked to grade the correctness of sentences on the Likert scale based on their native speaker intuition. The results were analysed using one-way ANOVA and t-test, and they revealed that the students preferred the sentences with Serbian translation equivalents, proving that they indeed have awareness of unjustified anglicisms within their mother tongue.

Keywords: fully unjustified anglicisms, students, awareness, native speaker intuition, psycholinguistic approach 